\title{
Investigation of hydrochemical characteristics of groundwater in the Bukan basin, Northwest of Iran
}

\author{
Kaveh Pazand · Ardeshir Hezarkhani
}

Received: 29 April 2012/ Accepted: 12 July 2012/Published online: 3 August 2012

(C) The Author(s) 2012. This article is published with open access at Springerlink.com

\begin{abstract}
Hydrochemical investigations were carried out in Bukan area, Northwestern Iran, to assess chemical composition of groundwater. A total of 35 groundwater samples were collected and analyzed for major cations and anions. The domination of cations and anions was in the order of $\mathrm{Na}^{+}>\mathrm{Ca}^{2+}>\mathrm{Mg}^{2+}>\mathrm{K}^{+}$for cations and $\mathrm{HCO}_{3}{ }^{-}>\mathrm{SO}_{4}{ }^{2-}>\mathrm{Cl}^{-}$in anions. The similarity between rock and groundwater chemistries in the recharge area indicates a significant rock-water interaction. The hydrochemical types $\mathrm{Na}+\mathrm{HCO}_{3}+\mathrm{CL}+\mathrm{Mg}$ and $\mathrm{Na}+\mathrm{Cl}$ are the predominate forms in the groundwater, followed by water $\mathrm{Ca}+\mathrm{Mg}+\mathrm{SO}_{4}+\mathrm{Cl}$ and $\mathrm{Ca}+\mathrm{Mg}+\mathrm{HCO}_{3}$. Assessment of water samples according to exceeding the permissible limits prescribed by WHO for drinking purposes indicated that groundwater in study area is chemically suitable for drinking uses. The most dominant classes $\mathrm{C} 2-\mathrm{S} 2, \mathrm{C} 2-\mathrm{S} 1$ and $\mathrm{C} 3-\mathrm{S} 2$ were found in the studied area. The salinity hazard for water wells is classified as medium and high salinity.
\end{abstract}

Keywords Hydrochemical - Groundwater · Bukan

\section{Introduction}

The quality of groundwater at any point below the surface reflects the combined effects of many processes along the

K. Pazand ( $\square)$

Department of Mining Engineering, Science and Research Branch, Islamic Azad University, Tehran, Iran

e-mail: kaveh.pazand@gmail.com

\section{A. Hezarkhani}

Department of Mining, Metallurgy and Petroleum Engineering, Amirkabir University, Hafez Ave. No. 424, Tehran, Iran groundwater flow path. Chemical reactions such as weathering, dissolution, precipitation, ion exchange and various biological processes commonly take place below the surface. Hydrogeochemical study is a useful tool to identify these processes that are responsible for groundwater chemistry (Jeevanandam et al. 2007). Water shortages have become an increasingly serious problem in Iran, especially in the arid and semi-arid regions of western Iran (Jalali 2006). Groundwater has become the major source of water supply for domestic, industrial and agricultural sectors of many countries. Iran is located in a semi-arid area with an average annual precipitation less than one-third of that of the world (Baghvand et al. 2010). Furthermore, spatial and temporal distribution of the regional precipitation is not integrated. Iran is one of 27 countries that are likely to face increasing water shortage crises between now and 2025, unless action is taken to reduce current water consumption (Bidhendi et al. 2007). Intense agricultural and urban development has placed a high demand on groundwater resources, especially in the Bukan region, and these resources are now at greater risk of contamination. The increasing exploitation due to farming frequently causes deterioration in water quality. Therefore, variations in natural and human activities reflect spatial variations in the hydrochemical parameters of the groundwater. The importance of water quality in human health has also recently attracted a great deal of interest (Pazand et al. 2011).The importance of the groundwater in the area should not be underestimated because they are sources of water resource for drinking and agricultural purposes, not only for the people living in this area but also for those who live in the surrounding areas (Pazand et al. 2012). Hydrochemical evaluation of groundwater systems are usually based on the availability of a large amount of information concerning groundwater chemistry. Groundwater chemistry, in turn, depends on a number of factors, such as 
general geology, degree of chemical weathering of the various rock types, quality of recharge water, and inputs from sources other than water-rock interaction. Such factors and their interactions result in a complex groundwater quality (Guler and Thyne 2004; Giridharan et al. 2008). In the Bukan area, agriculture is the most important economic activity; thus, a hydrogeochemical investigation was carried out to identify groundwater geochemistry and its suitability for irrigation and drinking purposes.

\section{Geological and hydrogeological setting}

The investigated area is located in the NW Iran and is part of the Bukan basin that lies between longitudes $45^{\circ} 32^{\prime} 3^{\prime \prime}$ to $46^{\circ} 21^{\prime} 48^{\prime \prime} \mathrm{E}$ and latitudes $36^{\circ} 10^{\prime} 30^{\prime \prime}$ to $36^{\circ} 49^{\prime} 32^{\prime \prime} \mathrm{N}$ with area occupies of about $2,885 \mathrm{Km}^{2}$ (Fig. 1).The area has a cold temperate climate and the air temperature is highest in August $\left(27.4{ }^{\circ} \mathrm{C}\right)$ and lowest in January $\left(-4.1^{\circ} \mathrm{C}\right)$ with an annual average of $15.2^{\circ} \mathrm{C}$. The climate of the study area is semiarid and its average annual rainfall is about $210 \mathrm{~mm}$, which $80 \%$ of it falls during the spring and winter seasons. Groundwater is an important water resource for drinking, agriculture, and industrial uses in the study area. Low precipitation and overexploitation of groundwater resources in recent years have caused an extensive groundwater level decline in this plain prohibiting further development of the aquifer (Fig. 2).

The geology of the Bukan basin in eastern part consists of Quaternary deposits over-lying volcanic such as andesite and tuff of Jurassic and Pliocene age while the western part of area was covered by the intrusive granite and

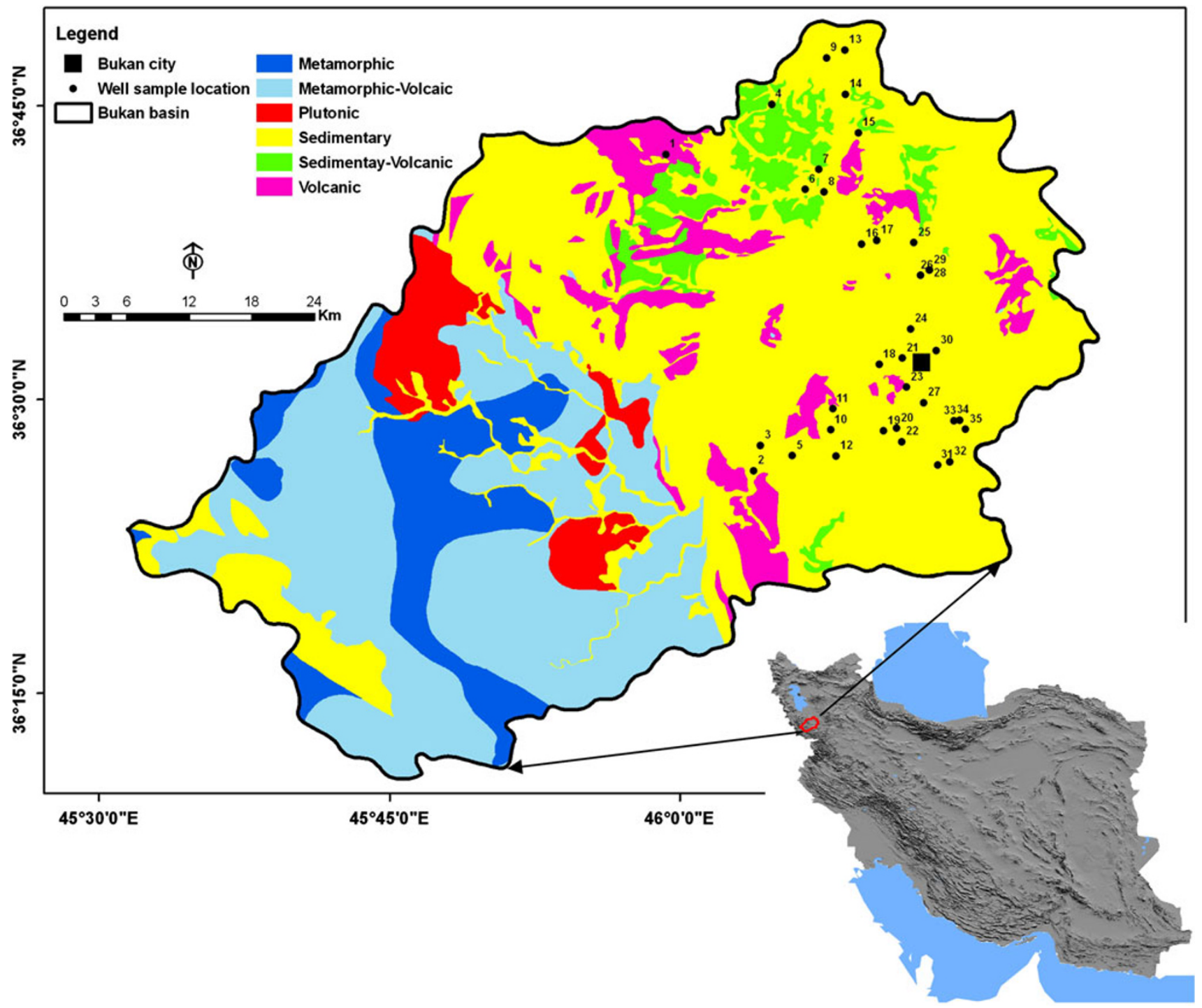

Fig. 1 Geological map and Study area location 


\section{Year}

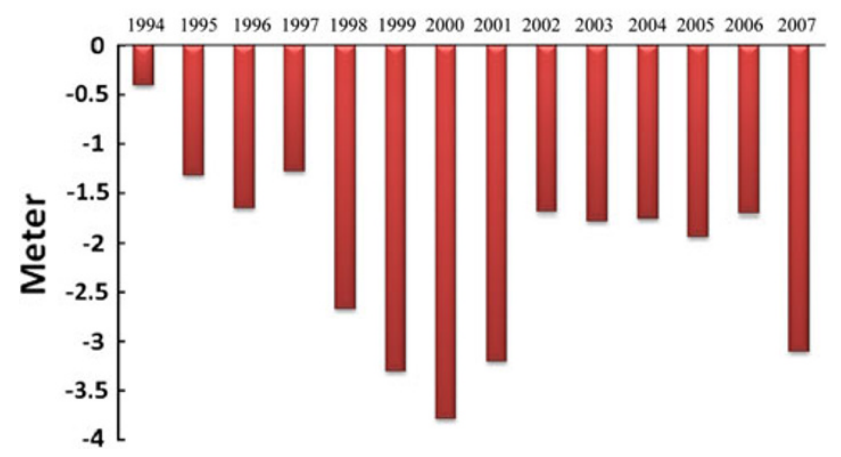

Fig. 2 Long-term and seasonal groundwater level fluctuation in Bukan aquifer

Table 1 Summary statistics of the analytical data and groundwater samples of the study area

\begin{tabular}{llrrrr}
\hline Parameters & Units & \multicolumn{1}{l}{ Max } & \multicolumn{1}{l}{ Min } & Mean & \multicolumn{1}{c}{$\mathrm{SD}$} \\
\hline $\mathrm{Na}$ & $\mathrm{mg} / \mathrm{l}$ & 33.56 & 3.74 & 14.81 & 6.59 \\
$\mathrm{~K}$ & $\mathrm{mg} / \mathrm{l}$ & 0.20 & 0.00 & 0.05 & 0.06 \\
$\mathrm{Mg}$ & $\mathrm{mg} / \mathrm{l}$ & 13.00 & 0.70 & 2.61 & 2.18 \\
$\mathrm{Ca}$ & $\mathrm{mg} / \mathrm{l}$ & 16.50 & 1.60 & 4.03 & 2.85 \\
$\mathrm{SO}_{4}$ & $\mathrm{mg} / \mathrm{l}$ & 20.00 & 0.40 & 2.18 & 3.35 \\
$\mathrm{Cl}$ & $\mathrm{mg} / 1$ & 19.70 & 0.30 & 1.44 & 3.26 \\
$\mathrm{HCO}_{3}$ & $\mathrm{mg} / 1$ & 9.70 & 1.40 & 4.58 & 1.94 \\
$\mathrm{pH}$ & - & 8.30 & 7.10 & 7.62 & 0.30 \\
$\mathrm{EC}$ & $\mu \mathrm{S} / \mathrm{cm}$ & $4,040.00$ & 260.00 & 722.29 & 647.67 \\
$\mathrm{TH}$ & $\mathrm{mg} / 1$ & 94.55 & 8.60 & 20.78 & 14.97 \\
$\mathrm{SAR}$ & - & 15.21 & 2.04 & 8.40 & 3.08 \\
\hline EC & & & & &
\end{tabular}

$E C$ electrical conductivity, $S A R$ sodium adsorption ratio, $T H$ total hardness, $S D$ standard deviation

metamorphic rocks contain phyllite and gneiss with Precambrian age (Fig. 1) (Eftekharnezhad 1973).

\section{Materials and methods}

In order to evaluate the quality of groundwater in study area, groundwater samples were collected from 35 shallow and deep wells and springs of the area during June 2006 (Fig. 1). The selected wells and springs are used for agricultural and domestic purposes. The samples were collected after $10 \mathrm{~min}$ of pumping and stored in polyethylene bottles. Immediately after sampling, $\mathrm{pH}$ and electrical conductivity (EC) were measured in the field using a portable $\mathrm{pH}$ meter. Water sample collected in the field were analyzed in the laboratory for cations $\left(\mathrm{Ca}^{2+}, \mathrm{Mg}^{2+}, \mathrm{Na}^{+}\right.$, $\left.\mathrm{K}^{+}\right)$and anions $\left(\mathrm{HCO}_{3}{ }^{-}, \mathrm{CO}_{3}{ }^{2-}, \mathrm{SO}_{4}{ }^{2-}, \mathrm{Cl}^{-}\right)$using the standard methods. Calcium $\left(\mathrm{Ca}^{2+}\right)$ and magnesium $\left(\mathrm{Mg}^{2+}\right)$ were determined titrimetrically using standard EDTA. Chloride $\left(\mathrm{Cl}^{-}\right)$was determined by the standard $\mathrm{AgNO}_{3}$ titration method. Carbonate $\mathrm{CO}_{3}{ }^{2-}$ and bicarbonate $\left(\mathrm{HCO}_{3}{ }^{-}\right)$were determined by titration with $\mathrm{HCl}$. Sodium $\left(\mathrm{Na}^{+}\right)$and potassium $\left(\mathrm{K}^{+}\right)$were measured by flame photometry, and sulfate $\mathrm{SO}_{4}{ }^{2-}$ by spectrophotometric turbidimetry (Rowell 1994) (Table 1).

\section{Groundwater chemistry}

The $\mathrm{pH}$ of the groundwater in the study area ranged from 7.1 to 8.3 with an average value of 7.62 , indicating an alkaline nature of the samples. The overall groundwater EC value is ranging from 260 to $4,040 \mu \mathrm{S} / \mathrm{cm}$. The large variation in EC is mainly attributed to geochemical processes prevailing in this region. The spatial variation of chemical parameters in the groundwater reflects the variation in the natural and human activity. The relative content of a cation or an anion is defined as the percentage of the relative amount of that ion to the total cations or anions, respectively (Pazand et al. 2011). The concentrations of $\mathrm{Ca}^{2+}, \mathrm{Mg}^{2+}, \mathrm{Na}^{+}$and $\mathrm{K}^{+}$ represent on average 18.76, 12.13, 68.88 and $0.23 \%$ of all the cations, respectively. Among the anions, the concentrations of $\mathrm{HCO}_{3}{ }^{-}, \mathrm{Cl}^{-}$and $\mathrm{SO}_{4}{ }^{2-}$ represent on average 55.87, 17.59 and $26.54 \%$, respectively. Thus, the order of cation and anion abundance is $\mathrm{Na}^{+}>\mathrm{Ca}^{2+}>\mathrm{Mg}^{2+}>\mathrm{K}^{+}$and $\mathrm{HCO}_{3}{ }^{-}>\mathrm{SO}_{4}{ }^{2-}>\mathrm{Cl}^{-}$, respectively. If halite dissolution is responsible for sodium, the $\mathrm{Na}^{+} / \mathrm{Cl}^{-}$ratio should be approximately equal to 1 , whereas a ratio greater than 1 is typically interpreted as $\mathrm{Na}$ released from silicate weathering reactions (Meyback 1987). In the present study, the $\mathrm{Na}^{+} / \mathrm{Cl}^{-}$ ratio of groundwater samples generally varies from 1.7 to 42.68 (Fig. 3). Samples having $\mathrm{Na}^{+} / \mathrm{Cl}^{-}$ratio greater than 1 indicated that an ion exchange process is prevalent in the study area and might have come from silicate weathering (Pazand et al. 2012). The chloro-alkaline index, CAI = $[\mathrm{Cl}-(\mathrm{Na}+\mathrm{K})] / \mathrm{Cl}$, is suggested by Schoeller (1977), which indicate the ion exchange between the groundwater and its host environment. If there is ion exchange of $\mathrm{Na}^{+}$ and $\mathrm{K}^{+}$from water with magnesium and calcium in the rock, the exchange is known as direct when the indices are positive. If the exchange is reverse then the exchange is indirect and the indices are found to be negative. The negative CAI values in Bukan basin suggest that magnesium and calcium from water are exchanged with sodium and potassium in rock favoring cation-anion exchange reactions (Fig. 3).

\section{Hydrochemical facies}

The term hydrochemical facies is used to describe the bodies of groundwater in an aquifer that different their chemical composition (Aghazadeh and Mogaddam 2011). The facies 
Fig. $3 \mathrm{Na} / \mathrm{Cl}$ ratio and $\mathrm{CAI}$ index of well samples in the study area

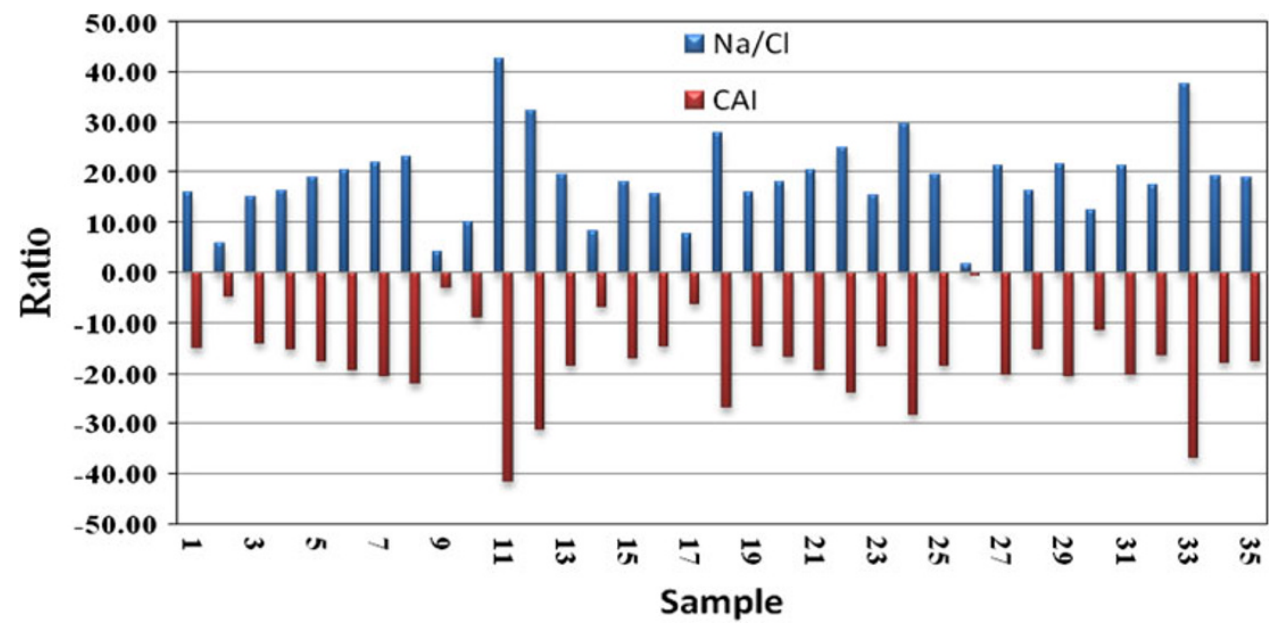

are a function of the lithology, solution kinetics and flow patterns of the aquifer (Raju et al. 2009). Large tables of analytical data are usually difficult to interpret regarding the variations in water quality. Graphs are useful for this purpose and several specialized types are in use. Piper diagram is one of them. Based on the dominant cations and anions, four water types were found for the water samples (Fig. 4):

$\mathrm{Na}+\mathrm{HCO}_{3}+\mathrm{CL}+\mathrm{Mg}, \quad \mathrm{Na}+\mathrm{Cl}, \quad \mathrm{Ca}+\mathrm{Mg}+$ $\mathrm{SO}_{4}+\mathrm{Cl}$ and $\mathrm{Ca}+\mathrm{Mg}+\mathrm{HCO}_{3}$ that represent 57.14, $31.42,5.72$ and $5.72 \%$ of the total number of water samples, respectively.

The $\mathrm{Na}+\mathrm{Cl}$ type of water is dominant in the southern part of the study area (Fig. 5) with $\mathrm{Na}^{+}$ranging from 6.52 to $21.27 \mathrm{mg} \mathrm{l}^{-1}$ and $\mathrm{Cl}^{-}$ranging from 0.3 to $1.9 \mathrm{mg} \mathrm{l}^{-1}$. Range and mean chemical compositions and standard deviation in the four sub-types of groundwater samples in study area are shown in Table 2.

\section{Groundwater quality and assessment}

Natural chemical composition of groundwater results from two main processes: the first are the atmospheric salts that coming from marine aerosols, dust and concentration by evaporation of dissolved salts in precipitation, and the second is the interaction of groundwater with the formation minerals (Pazand et al. 2011). A hydrogeological environment is a conceptual model of morphological, geological and climatic parameters that determine the main groundwater flow features in given area. Understanding the quality of groundwater is as important as its quantity because it is the main factor determining its suitability for drinking, domestic, agricultural, industrial and touristic purposes (Pazand et al. 2011).The analytical results of physical and chemical parameters of groundwater were compared with

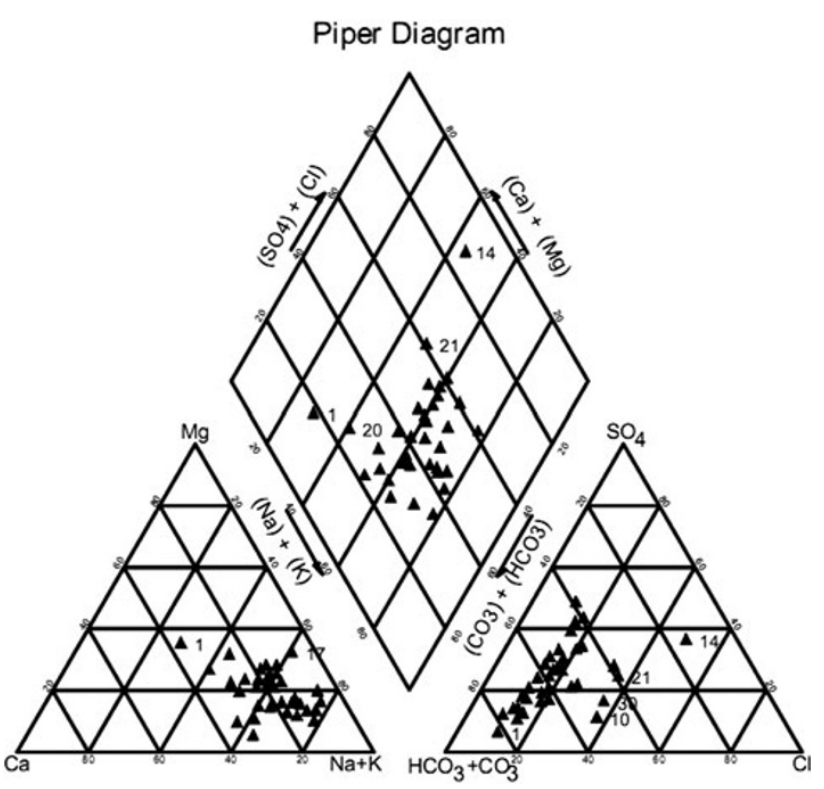

Fig. 4 The piper diagram for the groundwater samples of the study area

the standard guideline values as recommended by the World Health Organisation (2004) for drinking and public health purposes. According to the $\mathrm{WHO}$, the range of desirable $\mathrm{pH}$ values of water prescribed for drinking purposes is 6.5-9.2. There are no water samples with $\mathrm{pH}$ values outside of the desirable ranges. The degree of hardness in water is commonly based on the classification: (0-75) soft, (75-150) moderately hard, (150-300) hard, (300) very hard (Todd and Mays 2005). All samples except for one $(\mathrm{TH}=94.55)$ sample had a hardness degree between 8.6 and 41.95 , hence groundwaters are soft. In all the samples, the concentrations of anions and cations, such as $\mathrm{K}^{+}, \mathrm{Na}^{+}, \mathrm{Ca}^{2+}, \mathrm{SO}_{4}{ }^{2-}$ and $\mathrm{Mg}^{2+}$ are below the maximum acceptable level $(200,1,538$, 
Fig. 5 Distribution of water types in the groundwater of the study area

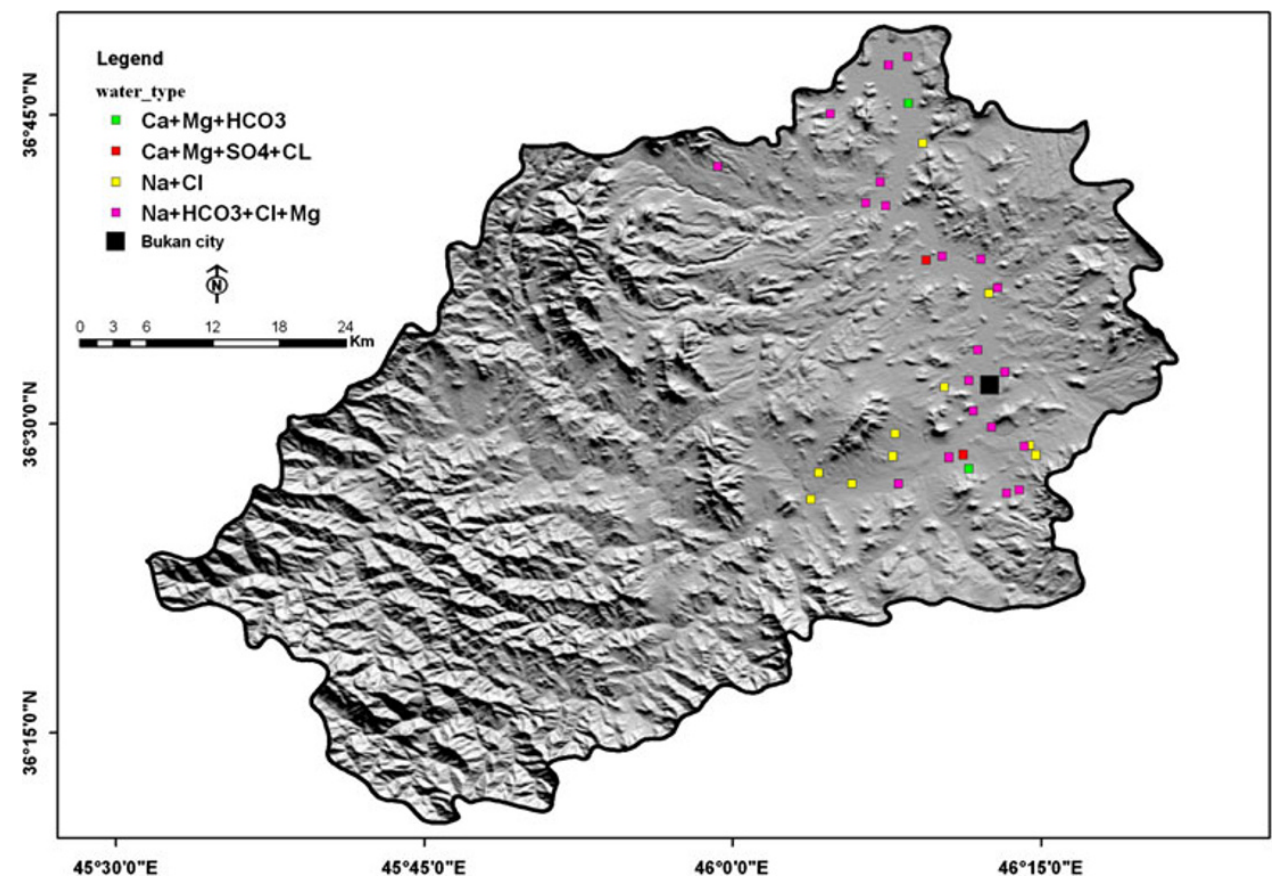

349, 1,492 and $133 \mathrm{mg} \mathrm{l}^{-1}$, respectively) for drinking waters (WHO 2004). The sodium adsorption ratio (SAR) is an important parameter for determining the suitability of groundwater for irrigation because it is a measure of alkali/sodium hazard to crops (Subramani et al. 2005). The sodicity hazard of water is generally described by the SAR:
$\mathrm{SAR}=\frac{\mathrm{Na}}{\sqrt{\frac{\mathrm{ca}+\mathrm{Mg}}{2}}}$

The ionic symbols indicate concentrations of the ions in the water in milliequivalents per liter. The calculated SAR ranged from 2.04 to 13.09 . In order to identify the availability of waters for irrigation use, the Wilcox classification diagram

Table 2 Range and mean chemical compositions and standard deviation in the sub-types of groundwater samples

\begin{tabular}{|c|c|c|c|c|c|c|c|c|c|c|}
\hline \multirow[t]{2}{*}{ Water type } & \multirow[t]{2}{*}{ Statistical parameters } & \multicolumn{7}{|c|}{ Cations and anions (mg/l) } & \multicolumn{2}{|c|}{ Physical parameters } \\
\hline & & $\mathrm{K}$ & $\mathrm{Na}$ & $\mathrm{Ca}$ & $\mathrm{Mg}$ & $\mathrm{Cl}$ & $\mathrm{HCO}_{3}$ & $\mathrm{SO}_{4}$ & $\mathrm{pH}$ & $\mathrm{EC}$ \\
\hline \multirow{4}{*}{$\mathrm{Na}+\mathrm{HCO}_{3}+\mathrm{CL}+\mathrm{Mg}$} & Maximum & 0.10 & 23.65 & 10.10 & 4.80 & 4.40 & 8.70 & 4.10 & 8.30 & $1,670.00$ \\
\hline & Minimum & 0.00 & 3.74 & 1.60 & 1.00 & 0.30 & 1.40 & 0.40 & 7.10 & 260.00 \\
\hline & Mean & 0.05 & 15.25 & 3.91 & 2.54 & 1.05 & 4.79 & 1.83 & 7.61 & 681.50 \\
\hline & SD & 0.05 & 5.64 & 2.28 & 1.24 & 0.88 & 2.08 & 1.20 & 0.33 & 341.93 \\
\hline \multirow[t]{4}{*}{$\mathrm{Na}+\mathrm{Cl}$} & Maximun & 0.15 & 21.27 & 5.60 & 4.80 & 1.90 & 5.50 & 5.45 & 8.00 & $1,030.00$ \\
\hline & Minimum & 0.00 & 6.52 & 2.20 & 0.70 & 0.30 & 2.40 & 0.45 & 7.20 & 330.00 \\
\hline & Mean & 0.03 & 11.86 & 3.30 & 1.94 & 0.71 & 3.74 & 1.45 & 7.67 & 525.45 \\
\hline & SD & 0.06 & 4.98 & 1.10 & 1.37 & 0.47 & 1.01 & 1.58 & 0.31 & 228.97 \\
\hline \multirow[t]{4}{*}{$\mathrm{Ca}+\mathrm{Mg}+\mathrm{SO}_{4}+\mathrm{Cl}$} & Maximun & 0.10 & 20.77 & 4.20 & 2.10 & 0.90 & 5.20 & 1.65 & 7.70 & 700.00 \\
\hline & Minimum & 0.00 & 5.97 & 3.90 & 1.80 & 0.60 & 4.80 & 0.60 & 7.40 & 560.00 \\
\hline & Mean & 0.05 & 13.37 & 4.05 & 1.95 & 0.75 & 5.00 & 1.13 & 7.55 & 630.00 \\
\hline & SD & 0.07 & 10.47 & 0.21 & 0.21 & 0.21 & 0.28 & 0.74 & 0.21 & 98.99 \\
\hline \multirow[t]{4}{*}{$\mathrm{Ca}+\mathrm{Mg}+\mathrm{HCO}_{3}$} & Maximun & 0.20 & 33.56 & 16.50 & 13.00 & 19.70 & 9.70 & 20.00 & 7.60 & $4,040.00$ \\
\hline & Minimum & 0.13 & 22.56 & 2.10 & 2.30 & 0.60 & 3.90 & 1.45 & 7.50 & 570.00 \\
\hline & Mean & 0.17 & 28.06 & 9.30 & 7.65 & 10.15 & 6.80 & 10.73 & 7.55 & $2,305.00$ \\
\hline & SD & 0.05 & 7.78 & 10.18 & 7.57 & 13.51 & 4.10 & 13.12 & 0.07 & $2,453.66$ \\
\hline
\end{tabular}


Fig. 6 Diagram of sodium adsorption ratio and salinity for the classification of groundwater for irrigation purposes

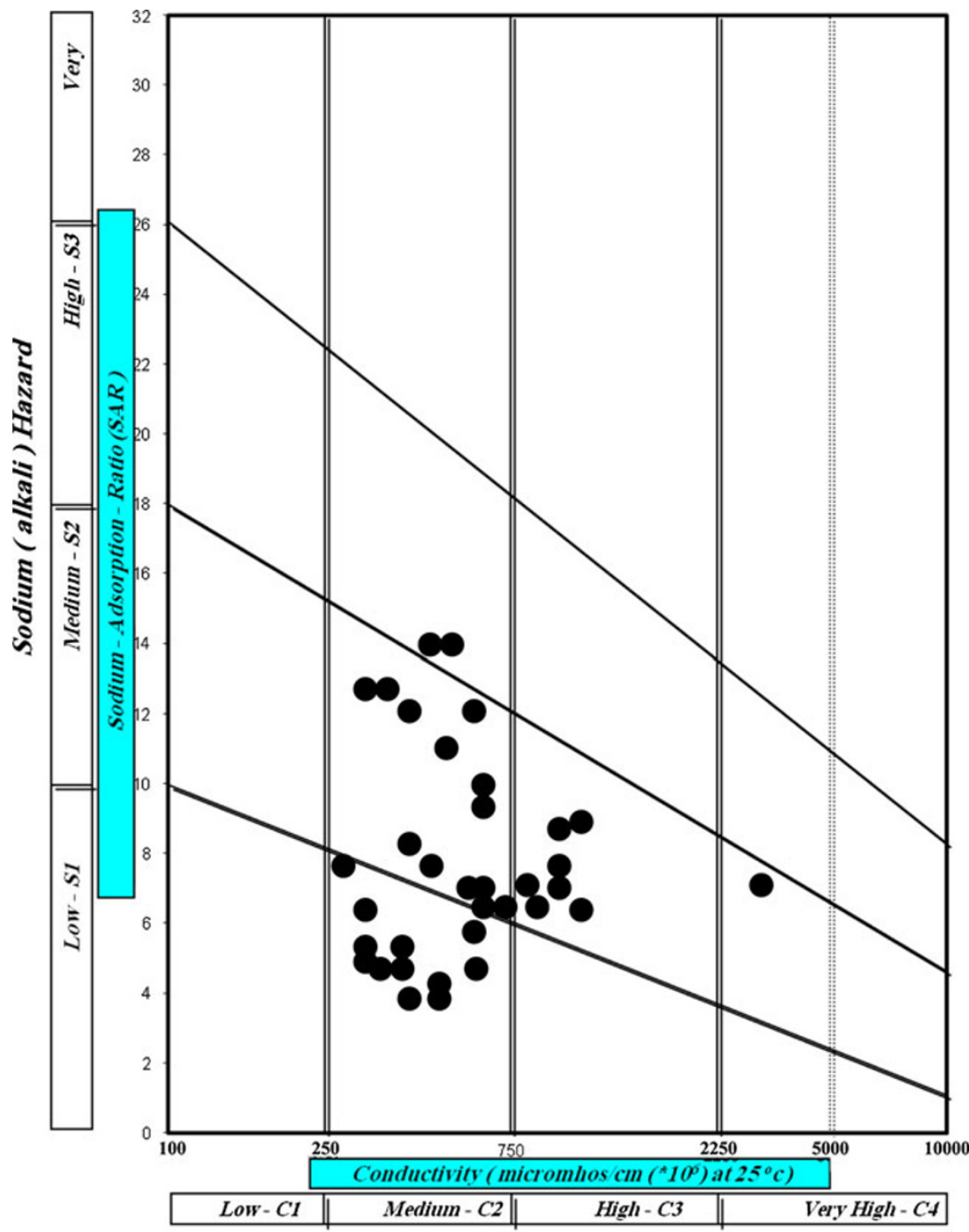

Salinity Hazard has been used (Fig. 6) (Pazand et al. 2012). According to this graph, water classes of water samples are mainly C2-S2 (37.14\%), C2-S1 (34.28\%), C3-S2 (20\%), C2-S3 $(5.71 \%)$ and $\mathrm{C} 4-\mathrm{S} 2(2.87 \%)$.

Salinity in C3-S2 class is high; hence, water cannot be used on soil with restricted drainage. Even with adequate drainage, special management for salinity control may be required, and plants with good salt tolerance should be selected. In C4-S2 classes, salinity is very high. Water is not suitable for irrigation under ordinary conditions but may be used under very special circumstances. In C2-S1, $\mathrm{C} 2-\mathrm{S} 2$ and $\mathrm{C} 2-\mathrm{S} 3$ classes, salinity is medium. Water can be used if a moderate amount of leaching occurs. These groundwaters can be used safely for irrigation on clay soil; however, selection of crops depending on salt tolerance should be carried out prior to cultivation.

\section{Conclusions}

The weathering of minerals is of prime importance in controlling the groundwater chemistry. In study area magnesium and calcium from water are exchanged with sodium and potassium in rock (volcanic rocks in basin). This study has demonstrated that the chemical composition of groundwater differs according to water types. The hydrochemical types $\mathrm{Na}+\mathrm{HCO}_{3}+\mathrm{CL}+\mathrm{Mg}$ and $\mathrm{Na}+\mathrm{Cl}$ dominate the largest part of the studied area. The sequence of the abundance of the major ions is in the following order: $\mathrm{Na}^{+}>\mathrm{Ca}^{2+}>\mathrm{Mg}^{2+}>$ $\mathrm{K}^{+}$and $\mathrm{HCO}_{3}{ }^{-}>\mathrm{SO}_{4}{ }^{2-}>\mathrm{Cl}^{-}$. Assessment of water samples according to exceeding the permissible limits prescribed by WHO for drinking purposes indicated that groundwater in study area is chemically suitable for drinking uses. The most dominant classes $\mathrm{C} 2-\mathrm{S} 2, \mathrm{C} 2-\mathrm{S} 1$ and $\mathrm{C} 3-\mathrm{S} 2$ were found in the 
studied area. The salinity hazard for water wells is classified as medium and high salinity. The $\mathrm{Na}^{+}$hazards in some samples are low to medium, an indication that these waters are suitable for irrigation in almost all soils with little danger of the development of $\mathrm{Na}^{+}$and salinity problem. Therefore, salinity is the principal concern in irrigated agriculture in Bukan areas. Special management for salinity control is required and plants with good salt tolerance should be selected. Maintaining soil organic matter levels and appropriate leaching is necessary to avoid the build-up of salts over time. Given the decline in aquifer water levels over the past years, must have a comprehensive program for the management of groundwater.

Open Access This article is distributed under the terms of the Creative Commons Attribution License which permits any use, distribution, and reproduction in any medium, provided the original author(s) and the source are credited.

\section{References}

Aghazadeh N, Mogaddam AA (2011) Investigation of hydrochemical characteristics of groundwater in the Harzandat aquifer, Northwest of Iran. Environ Monit Assess 176:183-195

Baghvand A, Nasrabadi T, Bidhendi NG, Vosoogh A, Karbassi A, Mehrdadi N (2010) Groundwater quality degradation of an aquifer in Iran central desert. Desalination 260:264-275

Bidhendi NG, Karbassi AR, Nasrabadi T, Hoveidi H (2007) Influence of copper mine on surface water quality. Int J Sci Technol 4(1):85-91

Eftekharnezhad AJ (1973) Geology map of Mahabad 1:250000 sheets. Geological Survey of Iran

Giridharan L, Venugopal T, Jayaprakash M (2008) Evaluation of the seasonal variation on the geochemical parameters and quality assessment of the groundwater in the proximity of River Cooum, Chennai, India. Environ Monit Assess 143:161-178

Guler C, Thyne GD (2004) Hydrologic and geologic factors controlling surface and groundwater chemistry in Indian WellsOwens Valley area, southeastern California, USA. J Hydrol 285: 177-198

Jalali M (2006) Chemical characteristics of groundwater in parts of mountainous region, Alvand, Hamadan, Iran. Environ Geol 51:433-446

Jeevanandam M, Kannan R, Srinivasalu S, Rammohan V (2007) Hydrogeochemistry and groundwater quality assessment of lower part of the Ponnaiyar River Basin, Cuddalore district, South India. Environ Monit Assess 132:263-274

Meyback M (1987) Global chemical weathering of surficial rocks estimated from river dissolved loads. Am J Sci 287:401-428

Pazand K, Hezarkhani A, Ghanbari Y, Aghavali N (2011) Groundwater geochemistry in the Meshkinshahr Basin of Ardabil Province in Iran. Environ Earth Sci. 65:871-879

Pazand K, Hezarkhani A, Ghanbari Y, Aghavali N (2012) Geochemical and quality assessment of groundwater of Marand Basin, East Azarbaijan Province, northwestern Iran. Environ Earth Sci. doi: $10.1007 / \mathrm{s} 12665-012-1557-7$

Raju NJ, Ram P, Dey S (2009) Groundwater quality in the lower Varuna river basin, Varanasi district, Uttar Pradesh. J Geol Soc India 73:178-192

Rowell DL (1994) Soil science: methods and applications. Longman and Scientific Technical, New York, p 350

Schoeller H (1977) Geochemistry of groundwater. In: Groundwater studies: an international guide for research and practice, Chap 15. UNESCO, Paris, pp 1-18

Subramani T, Elango L, Damodarasamy SR (2005) Groundwater quality and its suitability for drinking and agricultural use in Chithar River Basin, Tamil Nadu, India. Environ Geol 47: 1099-1110

Todd DK, Mays L (2005) Ground water hydrology. Wiley, USA

WHO (2004) Guidelines for drinking water quality, vol 1 recommendations, 3rd edn. WHO, Geneva 